\title{
Inbreeding on productive and reproductive traits of dairy Gyr cattle
}

\section{João Cruz Reis Filho', Rui da Silva Verneque ${ }^{2}$, Robledo de Almeida Torres ${ }^{3}$, Paulo Sávio Lopes $^{3}$, Fernanda Santos Silva Raidan ${ }^{4}$, Fabio Luiz Buranelo Toral ${ }^{5}$}

\author{
${ }^{1}$ Ministério da Agricultura, Pecuária e Abastecimento, Viçosa, MG, Brasil. \\ ${ }^{2}$ Embrapa Gado de Leite, Juiz de Fora, MG, Brasil. \\ ${ }^{3}$ Universidade Federal de Viçosa, Departamento de Zootecnia, Viçosa, MG, Brasil. \\ ${ }^{4}$ Universidade Federal de Minas Gerais, Programa de Pós-graduação em Zootecnia, Belo Horizonte, MG, Brasil. \\ ${ }^{5}$ Universidade Federal de Minas Gerais, Escola de Veterinária, Departamento de Zootecnia, Belo Horizonte, MG, Brasil.
}

\begin{abstract}
The objective of this study was to estimate genetic parameters and to evaluate the effects of inbreeding on productive and reproductive traits of dairy Gyr cattle. Single-trait animal models were used to estimate genetic parameters and solutions for inbreeding coefficients for milk (milk 305-d), fat (fat 305-d), protein (protein 305-d), lactose (lactose 305-d), and total solids (TS 305-d) yield up to 305 days of lactation, days in milk (DIM), age at first calving (AFC) and calving intervals (CI). The mean inbreeding coefficient was $2.82 \%$. The models with linear and quadratic effects of inbreeding coefficients fitted the data better than the models without or with only linear effect of inbreeding coefficient for all traits. The increase in inbreeding coefficient caused several losses in productive and reproductive traits of dairy Gyr cattle. Estimates of heritability for milk 305-d, fat 305-d, protein 305-d, lactose 305-d, TS 305-d, DIM, AFC, and CI were 0.28, 0.27, 0.22, 0.21, 0.22, 0.17, 0.20 , and 0.10 , respectively. It is possible to achieve genetic progress in productive traits (especially in milk $305-\mathrm{d}$ and fat $305-\mathrm{d}$ ) and age at first calving in dairy Gyr cattle through selection.
\end{abstract}

Key Words: dairy cattle, genetic parameter, heritability, inbreeding depression

\section{Introduction}

The Gyr (Bos indicus) breed, originating from India and introduced in Brazil between 1906 and 1962, has broad support from farmers in tropical and subtropical regions due to the adaptability to various production systems, especially those based on pastures. The dairy Gyr is a sub-population of Gyr, selected for milk production (Faria et al., 2009) and holds a genetic improvement program started in 1985, which, among other activities, carries the progeny test.

The reduced genetic basis of animals imported from India, the intensive use of a small number of proven bulls and the development and large-scale application of reproductive biotechnologies (artificial insemination, embryo transfer, and in vitro fertilization) increase the probability of coselection of individuals belonging to the same family. The sum of these factors caused the increment of inbreeding in dairy Gyr cattle (Reis Filho et al., 2010).

Effects of inbreeding on economic traits attract considerable interest of research, taking into account that the increment of inbreeding resulting from the selection

Received December 17, 2014 and accepted March 5, 2015.

Corresponding author: flbtoral@ufmg.br

http://dx.doi.org/10.1590/S1806-92902015000500002

Copyright (C) 2015 Sociedade Brasileira de Zootecnia. This is an Open Access article distributed under the terms of the Creative Commons Attribution Non-Commercial License, which permits unrestricted non-commercial use, distribution, and reproduction in any medium, provided the original work is properly cited. process seems inevitable. Several studies relate the increase of inbreeding in European breeds to the reduction of phenotypic means in traits of economic interest (Croquet et al., 2007; Gulisija et al., 2007), a phenomenon called inbreeding depression (Falconer and Mackay, 1996). Similar results were also observed in Bos indicus breeds, like Gyr (Queiroz et al., 1993) and Guzerat (Panetto et al., 2010). There are two possible causes of the decline of phenotypic means of quantitative traits by inbreeding. The first is that the favorable genes have a tendency to be dominant or partially dominant, and the second is the fact that heterozygous animals have a greater phenotypic value than the homozygous (Crow and Kimura, 1970). Because of the recent development of genetic improvement programs of the Gyr breed, new studies need to be conducted to determine the effects of inbreeding on economically important traits, and to support selection decisions and mating in Brazilian herds. The objectives of this study were estimate genetic parameters and evaluate the effects of inbreeding on productive and reproductive traits of dairy Gyr cattle.

\section{Material and Methods}

The data used in this study originated from the progeny test of dairy Gyr breed, coordinated by Embrapa Dairy Cattle and the Brazilian Association of Dairy Gyr Breeders (ABCGIL). The pedigree file used for this study included 
data of 27,610 animals, 3,709 of which had one or both parents unknown. The data file consisted of lactations started from 1960 to 2004, from 8,879 purebred Gyr cows, daughters of 916 bulls and 5,375 cows, distributed into 26 Brazilian herds.

Traits were divided into two groups: Productive - total milk yield up to 305 days (milk 305-d), total fat yield up to 305 days (fat 305-d), total protein yield up to 305 days (protein 305-d), total lactose yield up to 305 days (lactose 305-d), total solids yield up to 305 days (TS 305-d), and days in milk (DIM); and Reproductive - age at first calving (AFC) and calving interval (CI). Lactations with abnormal termination causes or with duration shorter than 90 days were deleted from the database. The age at first calving was the beginning of the first controlled lactation that occurred between 18 and 66 months of age. Calving intervals between 300 and 730 days were considered valid.

To grant consistency to the analyses, herd $\times$ year of calving and herd $\times$ year of birth classes were created. Records of milk 305-d, fat 305-d, DIM, and CI from herd $\times$ year of calving classes with less than five records were deleted. Records of protein 305-d, lactose 305-d, and TS 305-d from herd $\times$ year of calving with less than three records were also deleted. Records of AFC from herd $\times$ year of birth with less than three records were deleted (Table 1).
The inbreeding coefficient (Figure 1) of each animal in the pedigree, defined as the proportion of loci which have identical alleles by descent (Wright, 1923), was calculated by using the MTDFNRM (Multiple Trait Derivative Free Numerator Relationship Matrix) package, a component of the MTDFREML system (Boldman et al., 1995). The effect of individual inbreeding coefficient was assessed in singletrait animal models with variance components obtained by Restricted Maximum Likelihood (REML). For each trait, three different animal models were fit. In the first one, inbreeding coefficient was not included; in the second model, linear effect of inbreeding coefficient was fit; and in the last model, linear and quadratic effect of inbreeding coefficient were fit.

In matrix notation, the single-trait animal models could be represented as follows:

$$
y=X \beta+Z_{1} a+Z_{2} p+e,
$$

in which $y$ represents the vector of observations for each trait; $X$ is the incidence matrix of fixed effects; $\beta$ is the vector of solutions of fixed effects; $Z_{1}$ is the incidence matrix of random direct additive genetic effects; $a$ is the vector of solutions for direct additive genetic effects (breeding values); $Z_{2}$ is the incidence matrix of random direct permanent environmental effects; $p$ is the vector of solutions for direct permanent environmental effects;

Table 1 - Descriptive statistics of productive and reproductive traits of dairy Gyr cows

\begin{tabular}{|c|c|c|c|c|}
\hline Trait & $\mathrm{N}$ of animals & $\mathrm{N}$ of observations & Mean & Standard error \\
\hline \multicolumn{5}{|l|}{ Productive } \\
\hline Total milk yield up to $305-\mathrm{d}, \mathrm{kg}$ & 8,860 & 24,045 & $2,590.9$ & 5.34 \\
\hline Total fat yield up to $305-\mathrm{d}, \mathrm{kg}$ & 6,136 & 15,211 & 125.1 & 0.32 \\
\hline Total protein yield up to $305-\mathrm{d}, \mathrm{kg}$ & 2,449 & 5,034 & 97.2 & 0.47 \\
\hline Total lactose yield up to $305-\mathrm{d}, \mathrm{kg}$ & 2,425 & 4,960 & 107.1 & 0.60 \\
\hline Total solids yield up to $305-\mathrm{d}, \mathrm{kg}$ & 2,423 & 4,956 & 368.7 & 1.82 \\
\hline Days in milk, days & 8,860 & 24,045 & 299.5 & 0.37 \\
\hline \multicolumn{5}{|l|}{ Reproductive } \\
\hline Age at first calving, months & 6,236 & 6,236 & 44.3 & 0.06 \\
\hline Calving interval, days & 5,613 & 14,205 & 492.5 & 0.81 \\
\hline
\end{tabular}

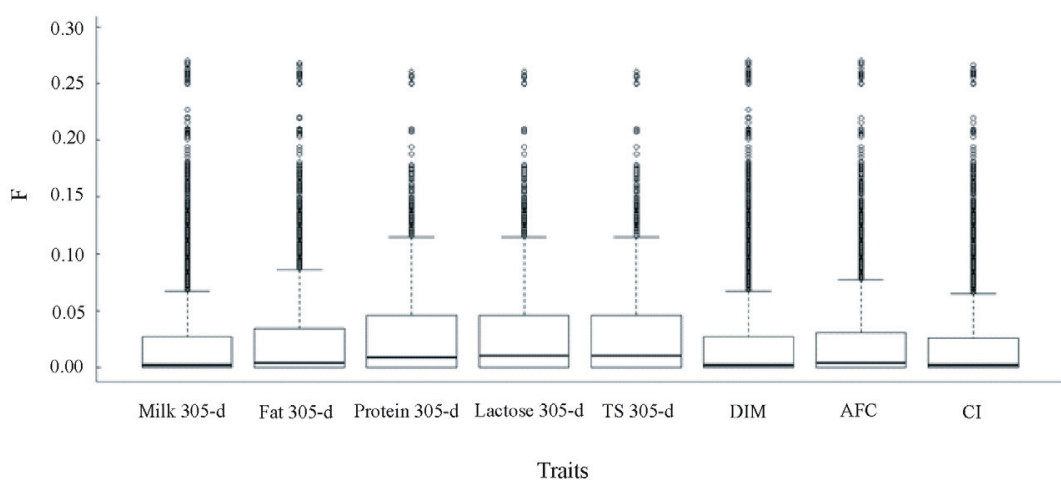

Figure 1 - Distributions of inbreeding coefficients (F) for dairy Gyr cows with records for total milk (Milk 305-d), fat (Fat 305-d), protein (Protein 305-d), lactose (Lactose 305-d), solid (TS 305-d) yield up to 305 days, days in milk (DIM), age at first calving (AFC) and calving interval $(\mathrm{CI})$. 
and $e$ is the vector of random residuals. The fixed effects for productive and $\mathrm{CI}$ analysis were: herd, year $\times$ calving season, linear and quadratic effects of age at calving, and linear and quadratic individual coefficients of inbreeding (according to the model). The fixed effects for AFC analysis were: herd $\times$ birth year, birth season, and linear and quadratic individual coefficients of inbreeding (according to the model). Calvings occurring between April and September formed calving season 1, and calving season 2 comprehended the remaining months, except for three herds located in the Northeast of Brazil, where the opposite was considered. The birth seasons were obtained according to the same criteria used for the definition of calving seasons. Direct additive genetic and residual effects were included for all traits and direct permanent environmental effect was not considered for AFC.

Estimates of variance components and fixed effects solutions according to REML were obtained with the REMLF90 program (Misztal et al., 2002). Convergence criteria were absolute squared differences between subsequent estimates $<10^{-10}$. Fits of different models were compared by examining the Akaike information criteria (AIC). Effects of inbreeding were estimated from the solutions of regression coefficients.

\section{Results and Discussion}

Models with linear and quadratic effect of inbreeding coefficient (F) fitted better the data than the models without or with only linear effect of inbreeding for all traits, according to AIC (Table 2). The productive and reproductive losses per $1 \%(0.01$ in $\mathrm{F})$ in inbreeding coefficient depended on the level of inbreeding (Figures 2 to 9). Inbreeding depression reduced milk 305-d (Figure 2), lactose 305-d (Figure 5), TS 305-d (Figure 6), and DIM (Figure 7) throughout the interval of $F$ ( 0 to 0.27$)$. Fat $305-\mathrm{d}$ reduced in the interval of $0<\mathrm{F}<0.241$ and increased thereafter (Figure 3). Protein 305-d had a small increase from $\mathrm{F}=0$ to $\mathrm{F}=0.051$ and decreases with $\mathrm{F}>0.051$ (Figure 4).

Results similar of those presented in this study, in which there was a linear effect of inbreeding coefficient on milk, fat, and protein production, have been reported with several dairy breeds such as Brown Swiss, Holstein, and Jersey (Casanova et al., 1992; Thompson et al., 2000a,b). In the Gyr breed, Queiroz et al. (1993) also observed a linear decrease in milk yield and DIM due to the increase

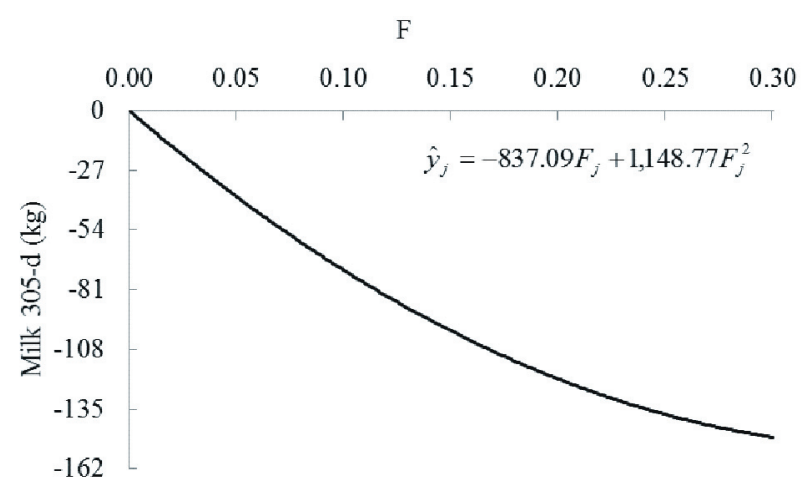

Figure 2 - Effect of inbreeding coefficients (F) on total milk yield up to 305 days (Milk 305-d) in dairy Gyr cattle.

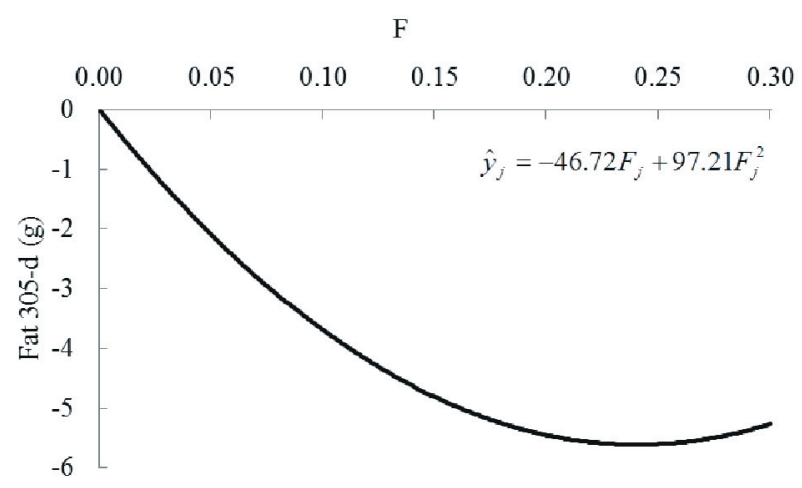

Figure 3 - Effect of inbreeding coefficients (F) on total fat yield up to 305 days (Fat 305-d) in dairy Gyr cattle.

Table 2 - Akaike information criteria (AIC) for analysis of productive and reproductive traits of dairy Gyr cattle with different models

\begin{tabular}{|c|c|c|c|}
\hline Trait & $\begin{array}{l}\text { Without effect of inbreeding } \\
\text { coefficient }\end{array}$ & $\begin{array}{c}\text { Linear effect of inbreeding } \\
\text { coefficient }\end{array}$ & $\begin{array}{l}\text { Linear and quadratic effect of } \\
\text { inbreeding coefficient }\end{array}$ \\
\hline \multicolumn{4}{|l|}{ Productive } \\
\hline Total milk yield up to $305-\mathrm{d}, \mathrm{kg}$ & 386,338 & 386,317 & 386,294 \\
\hline Total fat yield up to $305-\mathrm{d}, \mathrm{kg}$ & 152,365 & 152,352 & 152,339 \\
\hline Total protein yield up to $305-\mathrm{d}, \mathrm{kg}$ & 48,865 & 48,857 & 48,843 \\
\hline Total lactose yield up to $305-\mathrm{d}, \mathrm{kg}$ & 50,621 & 50,612 & 50,599 \\
\hline Total solids yield up to $305-\mathrm{d}, \mathrm{kg}$ & 61,450 & 61,333 & 61,318 \\
\hline Days in milk, days & 261,647 & 261,640 & 261,628 \\
\hline \multicolumn{4}{|l|}{ Reproductive } \\
\hline Age at first calving, months & 36,202 & 36,181 & 36,162 \\
\hline Calving interval, days & 169,003 & 168,993 & 168,978 \\
\hline
\end{tabular}


in the inbreeding coefficient. It is important to highlight that only the linear effect of inbreeding was evaluated in these cited papers.

According to Croquet et al. (2007), few studies have tested linear and curvilinear regressions in real situations with large databases. Nevertheless, these authors evaluated both models and concluded that the former would be the best

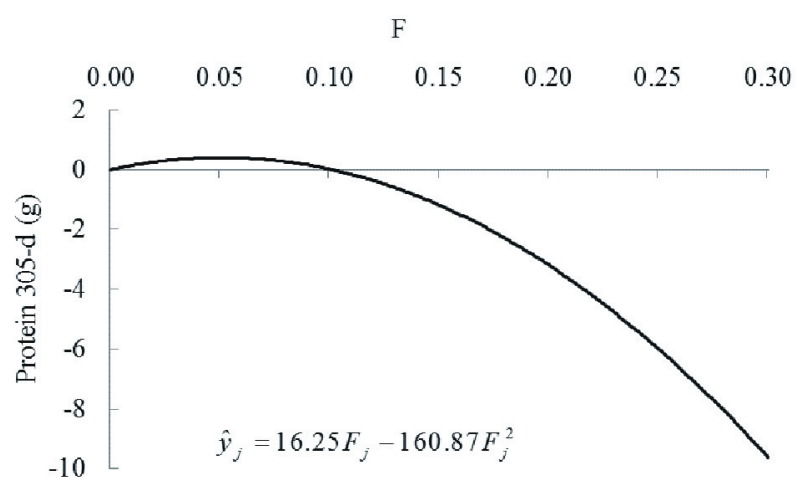

Figure 4 - Effect of inbreeding coefficients (F) on total protein yield up to 305 days (Protein 305-d) in dairy Gyr cattle.

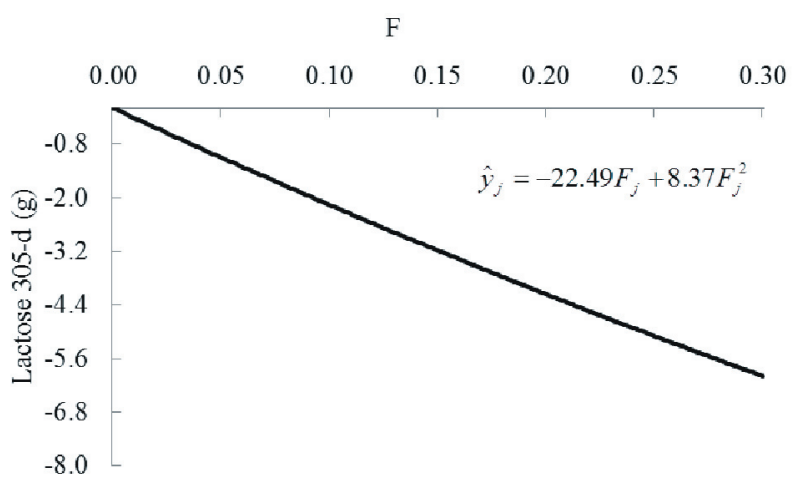

Figure 5 - Effect of inbreeding coefficients (F) on total lactose yield up to 305 days (Lactose 305-d) in dairy Gyr cattle.

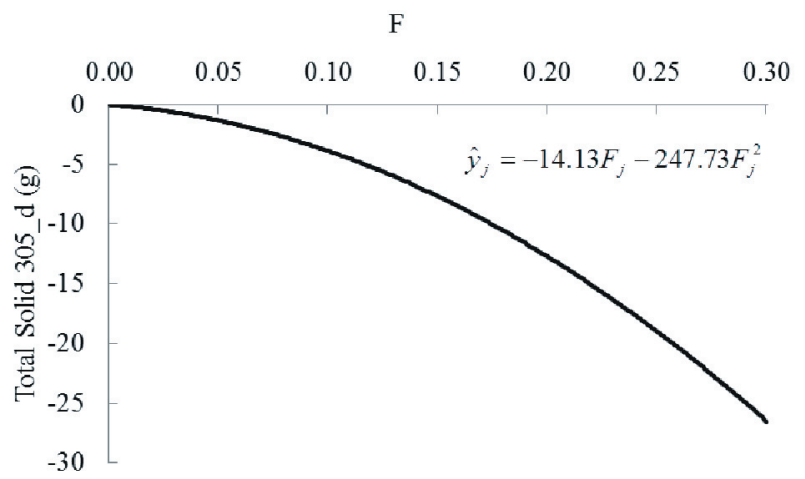

Figure 6 - Effect of inbreeding coefficients (F) on total solid yield up to 305 days in dairy Gyr cattle. options to describe the effect of inbreeding on production traits. The results obtained with dairy Gyr cattle (Table 2) corroborate those presented by Croquet et al. (2007). The positive and negative estimates of linear and quadratic effects of F, respectively, on milk 305-d, fat 305-d, and lactose 305-d in dairy Gyr cattle show that inbreeding depression tends to reduce with increase of $\mathrm{F}$.

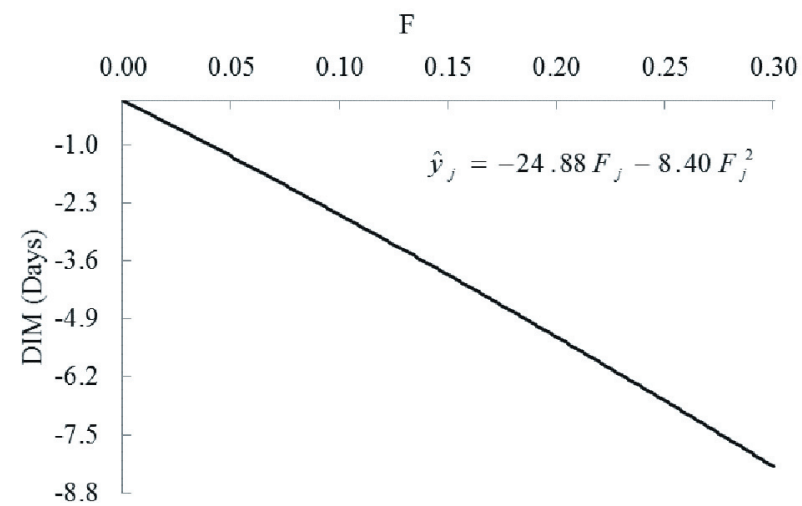

Figure 7 - Effect of inbreeding coefficients (F) on days in milk (DIM) in dairy Gyr cattle.

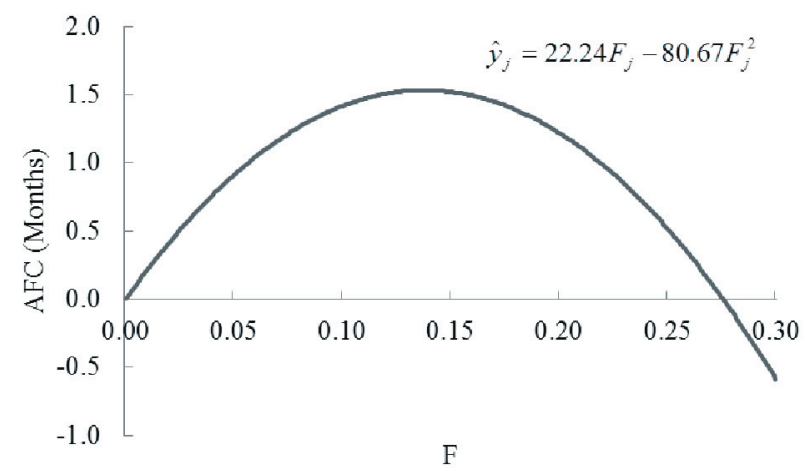

Figure 8 - Effect of inbreeding coefficients (F) on age at first calving (AFC) in dairy Gyr cattle.

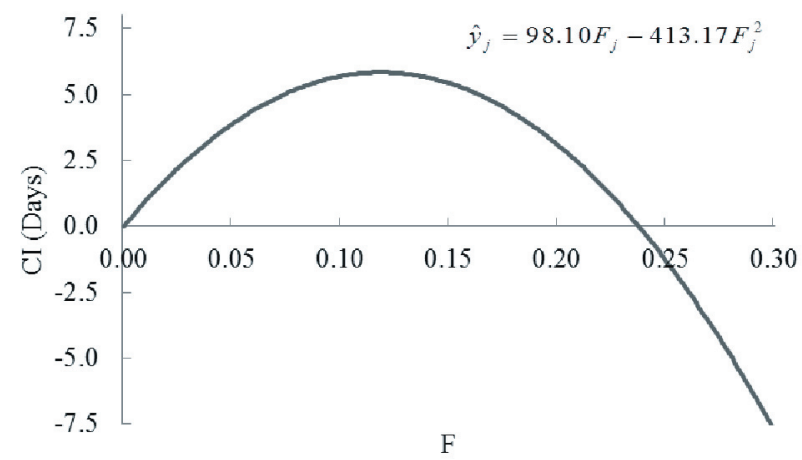

Figure 9 - Effect of inbreeding coefficients (F) on calving interval (CI) in dairy Gyr cattle. 
Kristensen and Sorensen (2005) highlighted that the non-linearity of inbreeding depression would be difficult to interpret because there are different elements that are not directly related to inbreeding. The authors cited as the first example the possibility of confounding between inbreeding trends and variation in the environment, because the distribution of animals between different classes of inbreeding is influenced by time.

Another element that could interfere with the interpretation of curvilinearity of inbreeding depression would be the assumption of the independence and homoscedasticity of the inbreeding coefficients (Lynch, 1988). A third element would be the deviation in the expected ratio of loci identical by descent for the actual ratio (Weir et al., 1980). Croquet et al. (2007) add that losses in milk 305 -d for each $1 \%$ increment in inbreeding can also be explained by the survival of genetically superior individuals with high inbreeding coefficients. In this case, the selection process acts by eliminating inbred animals that express deleterious recessive alleles of major effect. This may produce non-linearity in the relationship between a trait and the inbreeding level (Gulisija et al., 2007) and cause imbalance of the number of animals in different inbreeding levels. This imbalance can be explained by the choice of breeders to avoid mating with related individuals or even incomplete pedigree files (Croquet et al., 2007).

The estimates of AFC and CI increase up to $\mathrm{F}=0.138$ (Figure 8) and $\mathrm{F}=0.119$ (Figure 9), respectively, and reduce thereafter. These results did not agree with the generalization that inbreeding tends to reduce fitness (Falconer and Mackay, 1996). Smith et al. (1998) found a linear effect of F on AFC and first CI in the Holstein breed. However, non-significant inbreeding effects on these traits were found by Queiroz et al. (1993) in Gyr, Dias et al. (1994) in Caracu, and Falcão et al. (2001) for CI in Brown Swiss.

According to Queiroz et al. (1993), Dias et al. (1994), and Falcão et al. (2001), some heifers and cows with reproductive problems (caused by genetics or environment) do not have AFC and CI records because they have to calve at least once (for $\mathrm{AFC}$ recording) and twice (for $\mathrm{CI}$ recording). The numbers of cows with $\mathrm{F}>0.138$ (AFC) and $\mathrm{F}>0.119$ (CI) were 168 (out of 6,236) and 265 (out of 5,613), respectively, and indicate that estimates of inbreeding depression for $\mathrm{F}>0.138$ and $\mathrm{F}>0.119$ could be biased. Bias in the evaluation of $\mathrm{AFC}$ and $\mathrm{CI}$ can also be caused by management practices, e.g.: problems with perception of heat cycles in Gyr (silent heat); the common practice of delaying breeding of lactating cows for fear of drop in milk production; the non-identification, in the database studied, of donor cows subjected to embryo transfer and in vitro fertilization programs; and or the culling of inbred cows with low reproductive efficiency, since the analyzed herds have commercial purposes.

The results of this study suggest that the relationships between the quantitative traits and inbreeding may be more complex than expected, under the hypothesis of additive and dominant effects to be the only responsible for the genetic differences between the animals. If partial dominance and overdominance are the only non-additive genetic effects, the inbreeding depression in a trait is a linear function of the inbreeding coefficient. If epistatic interactions between genes are also responsible for a significant part of this type of gene action, the reduction in phenotypic means can be represented by a nonlinear function of the inbreeding coefficient (Lynch and Walsh, 1998). Thus, the results of this paper suggest that the epistatic effects can also control a significant part of the variation observed for productive and reproductive traits.

Estimates of heritability for productive traits and AFC were moderate (from 0.17 to 0.28 ; Table 3). Estimates of heritability for milk 305-d, fat 305-d, and DIM were higher than the previously values of 0.21 and 0.24 (Balieiro et al., 2000; Lagrota et al., 2010), 0.21 (Balieiro et al., 2000), and 0.11 (Balieiro et al., 2000), respectively, reported in

Table 3 - Genetic parameters ${ }^{1}$ of productive and reproductive traits of dairy Gyr cattle

\begin{tabular}{|c|c|c|c|c|c|}
\hline Trait & $\hat{\sigma}_{a}^{2}$ & $\hat{\sigma}_{p}^{2}$ & $\hat{\sigma}_{e}^{2}$ & $\hat{h}^{2}$ & $\hat{c}^{2}$ \\
\hline \multicolumn{6}{|l|}{ Productive } \\
\hline Total milk yield up to $305-\mathrm{d}$ & $208,900.00$ & $146,700.00$ & $402,000.00$ & 0.28 & 0.19 \\
\hline Total protein yield up to $305-\mathrm{d}$ & 255.70 & 233.70 & 678.60 & 0.22 & 0.20 \\
\hline Total lactose yield up to $305-\mathrm{d}$ & 386.80 & 309.30 & $1,179.00$ & 0.21 & 0.16 \\
\hline Total solids yield up to $305-\mathrm{d}$ & $3,728.00$ & $3,308.00$ & $10,140.00$ & 0.22 & 0.19 \\
\hline Age at first calving & 5.19 & - & 20.49 & 0.20 & - \\
\hline Calving interval & 975.20 & 693.20 & $7,840.00$ & 0.10 & 0.07 \\
\hline
\end{tabular}


Gyr cattle. The estimated heritability for AFC is in the interval between 0.17 (Balieiro et al., 1999) and 0.22 (Santana Júnior et al., 2010) in the same breed. These results support the possibility of genetic progress though selection. The heritability estimate for CI was low (0.10). Balieiro et al. (1999) also reported a low heritability estimate for CI (0.06), indicating that environmental factors, like pre and postpartum nutritional management, are very important to explain differences of $\mathrm{CI}$ between animals.

Permanent environmental effects were also important for productive traits. Estimates of repeatability $\left(\hat{h}^{2}+\hat{c}^{2}\right)$ for productive traits were moderate to high (from 0.29 to 0.47 ). Estimates of repeatability for milk 305-d, fat 305-d, and DIM were very close to the values of $0.51,0.47$, and 0.32 reported by Balieiro et al. (2000). Balieiro et al. (1999) estimated repeatability of 0.17 for CI, which is the same value presented in this paper. For CI, and for productive traits as well, accuracies of genetic evaluation could be increased by means of repeated records in the same animal. However, this strategy can increase the generation interval and an optimum number of records for each animal should be defined to achieve an optimum genetic response per year.

\section{Conclusions}

The increase in inbreeding coefficient causes losses in productive and reproductive traits, and mating should be carefully design to avoid inbreeding depression in dairy Gyr cattle. It is possible to achieve genetic progress in productive traits (especially in milk 305-d and fat 305-d) and age at first calving in dairy Gyr cattle through selection.

\section{References}

Balieiro, E. S.; Pereira, J. C. C.; Verneque, R. S.; Pereira, C. S. and Bergmann, J. A. G. 1999. Estimativas de parâmetros genéticos e de tendência fenotípica, genética e de ambiente de algumas características reprodutivas na raça Gir. Arquivo Brasileiro de Medicina Veterinária e Zootecnia 51:423-429.

Balieiro, E. S.; Pereira, J. C. C.; Valente, J.; Verneque, R. S.; Balieiro, J. C. C. and Ferreira, W. J. 2000. Estimativas de parâmetros genéticos e de tendências fenotípica, genética e de ambiente de algumas características produtivas da raça Gir Leiteiro. Arquivo Brasileiro de Medicina Veterinária e Zootecnia 52:266-275.

Boldman, K. G.; Kriese, L. A. and Van Vleck, L. D. 1995. A manual for use of MTDFREML. A Set of programs to obtain estimates of variances and covariances [DRAFT]. ARS-USDA, Beltsville.

Casanova, L.; Hagger, C.; Kuenzi, N. and Schneeberger, M. 1992. Inbreeding in Swiss Braunvieh and its influence on breeding values predicted from a repeatability animal model. Journal of Dairy Science 75:1119-1126.

Croquet, C.; Mayeres, P.; Gillon, A.; Hammami, H.; Soyeurt, H.; Vanderick, S. and Gengler, N. 2007. Linear and curvilinear effects of inbreeding on production traits for Walloon Holstein cows. Journal of Dairy Science 90:465-471.

Crow, J. F. and Kimura, M. 1970. An introduction to population genetics theory. Harper \& Row, New York.

Dias, A. S. C.; Queiroz, S. A. and Albuquerque, L. G. 1994. Efeito da endogamia em características reprodutivas de bovinos da raça Caracu. Revista da Sociedade Brasileira de Zootecnia 23:157-164.

Falcão, A. J. S.; Martins Filho, R.; Magnabosco, C. U.; Bozzi, R. and Lima, F. A. M. 2001. Efeitos da endogamia sobre características de reprodução, crescimento e valores genéticos aditivos de bovinos da raça Pardo-Suiça. Revista Brasileira de Zootecnia 30:83-92.

Falconer, D. S. and Mackay, T. F. C. 1996. Introduction to quantitative genetics. 4th ed. Longman, Essex, UK.

Faria, F. J. C.; Vercesi Filho, A. E.; Madalena, F. E. and Josahkian, L. A. 2009. Pedigree analysis in the Brazilian Zebu breeds. Journal of Animal Breeding and Genetics 126:148-153.

Gulisija, D.; Gianola, D. and Weigel, K. A. 2007. Nonparametric analysis of the impact of inbreeding on production in Jersey cows. Journal of Dairy Science 90:493-500.

Kristensen, T. C. and Sorensen, A. C. 2005. Inbreeding - Lessons from animal breeding, evolutionary biology, and conservation genetics. Animal Science 80:121-133

Lagrotta, M. R.; Euclydes, R. F.; Verneque, R. S.; Santana Júnior, M. L.; Pereira, R. J. and Torres, R. A. 2010. Relação entre características morfológicas e produção de leite em vacas da raça Gir. Pesquisa Agropecuária Brasileira 45:423-429.

Lynch, M. 1988. Design and analysis of experiments on random drift and inbreeding depression. Genetics 120:791-807.

Lynch, M. and Walsh, B. 1998. Genetics and analysis of quantitative traits. Sinauer Associates, Sunderland, MA.

Misztal, I.; Tsuruta, S.; Strabel, T.; Auvray, B.; Druet, T. and Lee, D. H. 2002. BLUPF90 and related programs (BGF90). Commun. No. 28-07. In: Proceedings of the $7^{\text {th }}$ World Congress on Genetics Applied to Livestock Production, Montpellier, France.

Panetto, J. C. C.; Gutiérrez, J. P.; Ferraz, J. B. S.; Cunha, D. G. and Golden, B. L. 2010. Assessment of inbreeding depression in a Guzerat dairy herd: effects of individual increase in inbreeding coefficients on production and reproduction. Journal of Dairy Science 93:4902-4912.

Queiroz, S. A.; Lôbo, R. N. and Martinez, M. L. 1993. Efeito da endogamia sobre algumas características de importância econômica na raça Gir. Revista da Sociedade Brasileira de Zootecnia 22:773-786.

Reis Filho, J. C.; Lopes, P. S.; Verneque, R. S.; Torres, R. A.; Teodoro, R. L. and Carneiro, P. L. S. 2010. Population structure of Brazilian Gyr dairy cattle. Revista Brasileira de Zootecnia 39:2640-2645.

Santana Júnior, M. L.; Lopes, P. S.; Verneque, R. S.; Pereira, R. J.; Lagrotta, M. R.; and Peixoto, M. G. C. D. 2010. Parâmetros genéticos de características reprodutivas de touros e vacas Gir Leiteiro. Revista Brasileira de Zootecnia 39:1717-1722.

Smith, L. A.; Cassel, B. G. and Pearson, R. E. 1998. The effects of inbreeding on the lifetime performance of dairy cattle. Journal of Dairy Science 81:2729-2737.

Thompson, J. R.; Everett, R. W. and Hammerschmidt, N. L. 2000a. Effects of inbreeding on production and survival in Holsteins. Journal of Dairy Science 83:1856-1864.

Thompson, J. R.; Everett, R. W. and Wolfe, C. W. 2000b. Effects of inbreeding on production and survival in Jerseys. Journal of Dairy Science 83:2131-2138.

Weir, B. S.; Avery, P. J. and Hill, W. G. 1980. Effect of mating structure on variation in inbreeding. Theoretical Population Biology 18:396-429.

Wright, S. 1923. Mendelian analysis of the pure breeds of livestock. I. The measurement of inbreeding and relationship. Journal of Heredity 14:339-348. 